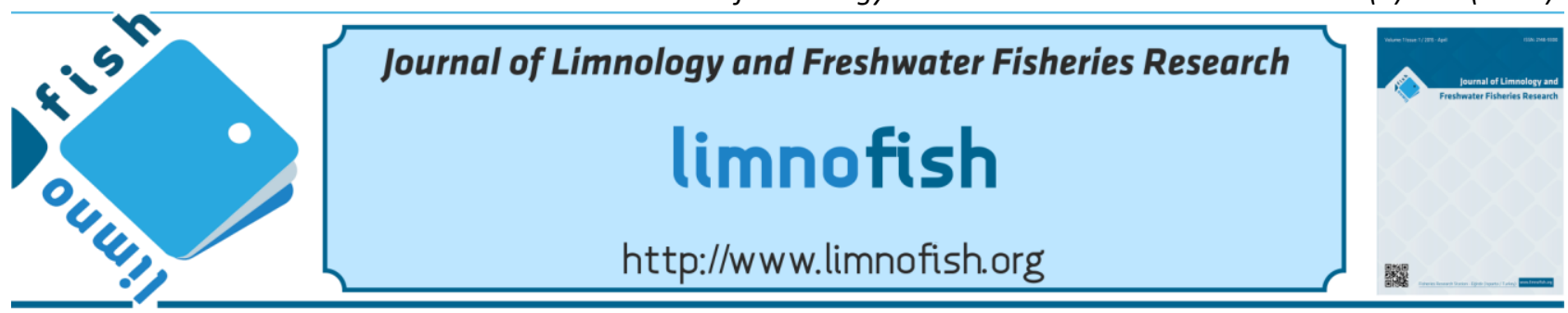

\title{
Thermal Tolerance of Turkish Crayfish (Astacus leptodactylus) Acclimated to Three Different Temperatures
}

\author{
Abdullatif ÖLÇÜLÜ ${ }^{1 *}$ (D), Metin KUMLU ${ }^{2}$ (D), H. Asuman YILMAZ ${ }^{2}$ (D), O. Tufan EROLDOĞAN ${ }^{2}$ (iD) \\ ${ }^{1}$ Fisheries Faculty, Munzur University, Tunceli, Turkey \\ ${ }^{2}$ Fisheries Faculty, Çukurova University, Adana, Turkey
}

\section{A B STRACT}

Critical thermal maxima (CTMax) and minima (CTMin) were determined for Turkish crayfish (Astacus leptodactylus) acclimated to 15,20 and $25^{\circ} \mathrm{C}$. CTMin and CTMax were $1.3,1.1$ and $2.0^{\circ} \mathrm{C}$, and $37.4,37.5$ and $38.7^{\circ} \mathrm{C}$, respectively. Thermal tolerance tests showed that acclimation temperatures $\left(15,20\right.$ and $\left.25^{\circ} \mathrm{C}\right)$ had significant effects on CTMin values of A. leptodactylus $(\mathrm{P} \leq 0.05)$. The area of thermal tolerance assessed using the CTMin and CTMax boundaries were calculated as $364^{\circ} \mathrm{C}^{2}$. The overall $A R R$ values were calculated as 0.07 for CTMin and 0.13 for CTMax values between 15 and $25^{\circ} \mathrm{C}$ acclimation tempera-tures. All the crayfish crumpled at $0.5^{\circ} \mathrm{C}$ and showed overall spasm at $32.0-33.0^{\circ} \mathrm{C}$. Farming A. leptodactylus in the southeastern part of the Mediterranean region may be practiced in terms of temperature tolerance.

Keywords: A. leptodactylus, CTMin, CTMax, thermal polygon, the acclimation response ratio

\section{ARTICLE INFO}

\section{RESEARCH ARTICLE}

Received : :11.05.2018

Revised : :05.10.2018

Accepted : :04.11.2018

Published : 25.04.2019

DOI:10.17216/LimnoFish.422903

\section{* CORRESPONDING AUTHOR}

aolculu@munzur.edu.tr

Phone : +904282131794

\section{Üç Farklı Sıcaklığa Alıştırılan Türk Kereviti (Astacus leptodactylus)'nin Sıcaklık Toleransı}

Öz: 15,20 ve $25^{\circ} \mathrm{C}^{\prime}$ ye alıştırılan Türk kereviti için kritik termal maksima (CTMax) ve minima (CTMin) değerleri belirlenmiştir. CTMin ve CTMax değerleri sırasıyla $1,3,1,1$ ve 2,0 ile $37,4,37,5$ ve $38,7^{\circ} \mathrm{C}$ 'dir. Sicaklık tolerans testleri alıștırma sıcaklıklarının $\left(15,20\right.$ ve $\left.25^{\circ} \mathrm{C}\right)$ A. leptodactylus CTMin değerlerine önemli etkilerde bulunduklarını göstermiştir $(\mathrm{P} \leq 0,05)$. Sicaklık tolerans alanı CTMin ve CTMax sınırları ile değerlendirilerek $364^{\circ} \mathrm{C}^{2}$ olarak hesaplanmıştır. Genel olarak 15 ile $25{ }^{\circ} \mathrm{C}$ arası alıştırma sıcaklıklarında, alıştırma tepki oranı (ARR) 0,07 ile 0,13 olarak hesaplananmıştır. Kerevitlerin tamamı $0,5^{\circ} \mathrm{C}^{\prime}$ de kıvrılma ve geneli 32,0- 33, $0^{\circ} \mathrm{C}$ 'de kasılma göstermiştir. Akdeniz bölgesinin güneydoğu kesiminde A. leptodactylus yetiştiriciliği sicaklık toleransı açısından uygun olabilir.

Anahtar kelimeler: A. leptodactylus, CTMin, CTMax, termal poligon, alıştırma tepki oranı

\section{How to Cite}

Ölçülü A, Kumlu M, Yılmaz HA, Eroldoğan OT, 2019. Thermal Tolerance of Turkish Crayfish (Astacus leptodactylus) Acclimated to Three Different Temperatures. LimnoFish. 5(1): 1-5. doi: 10.17216/LimnoFish.422903

\section{Introduction}

Survival, reproduction, and growth of poikilothermal aquatic organisms are intimately influenced by temperature fluctuations in their environments. Ectothermic animals use a combination of behavioral and physiological mechanisms to maintain their body temperatures within a narrow range, even under varied environmental conditions (Salas et al. 2014). The thermal preference of a species, therefore, corresponds closely with temperatures that maximize growth and other physiological processes (Huey and Stevenson 1979; Diaz et al. 2011; Tepler et al. 2011). The thermal limits tolerated by an organism are set genetically and are adaptive in determining the geographical distribution of a species (Simčič et al. 2014).

One of the approaches to quantify lower and upper-temperature tolerance of aquatic animals in the laboratory is known as the critical thermal methodology (CTM) (Cowles and Bogert, 1944). Thermal tolerance is quantified through the determination of the critical thermal maxima (CTMax) where the temperature is increased gradually until a critical point (lost of equilibrium) is reached (Kumlu et al. 2010a; González et al. 2010). The acclimation response ratio $(A R R)$ is an index of the magnitude of the thermal acclimation of an organism (Claussen 1977; Herrera et al. 1998; Díaz 
et al. 2002; Pérez et al. 2003; Díaz et al. 2004; Re et al. 2005). It is suggested that crustacean species that inhabit cold and temperate regions have low values of $A R R$, in contrast to those from subtropical and tropical regions, which present high ARR values; this indicates that the $A R R$ values are dependent on the geographic gradient where the organisms are distributed. Attributes of thermal tolerance polygons provide important insights into fish ecology and distribution and have been used to identify temperature-related survival tactics (Bennett and Beitinger 1997). The usefulness of thermal tolerance polygons lies inheritability to impart markedly more information than tolerance endpoints alone. Overall polygon area (reported as ${ }^{\circ} \mathrm{C}^{2}$ ) provides a convenient and useful comparative index of eurythermicity between species (Eme and Bennett 2009).

Turkish crayfish (A. leptodactylus) is accepted as a cold-water species with high economic value (Holdich 1993; Wickins and O'C Lee 2003; Harlioğlu 2004). The knowledge of the critical thermal minima and maxima provides a relevant ecological index since the Turkish crayfish in nature can find such spatial temperatures temporarily, as acute fluctuations outside of their limit of tolerance. The CTM provides a relevant and ecological index when it is applied to Turkish crayfish (A. leptodactylus) in its habitat. Paladino et al. (1980) mentioned that, in aquaculture, it is highly important to know CTMax and CTM values as they are indicators of the thermal resistance of organisms. Firkins (1993) reported thermal tolerance values for the A. leptodactylus originating from England; however, basic CTM studies are necessary to implement at different acclimation temperatures for A. leptodactylus originating from Turkey. Therefore, to detect geographic influences on thermal tolerance values in crayfish, research is needed that allows for direct comparison.

The aim of this study was to determine the critical thermal maximum and minimum, acclimation response ratio (ARR) and the zone of thermal preference of Turkish crayfish acclimated to three temperatures in order to evaluate the possibility of culturing the species in the south eastern region of the Mediterranean of Turkey.

\section{Materials and Methods \\ Critical Thermal Tolerance}

Sub-adult crayfish were caught in the Keban Dam Lake and transported in styrofoam boxes with wet towels to the laboratory of Çukurova University, Faculty of Fisheries (Adana - Turkey). The organisms were placed in a $1000-\mathrm{L}$ tank, provided with a biological filter at $20^{\circ} \mathrm{C}$ for 1 -week for adaptation to indoor culture conditions. Each group was then acclimated to 15,20 and $25^{\circ} \mathrm{C}$ in thermostatically controlled tanks at a rate of $1^{\circ} \mathrm{C}$ increase or decrease per day. The animals were cultured at the respective temperatures for a period of 35 days prior to the onset of the experiment in round fibreglass tanks (300-L) in order to stabilize their physiology and allow metabolic compensation in flow through rearing systems. Each tank was fitted with 25 plastic pipes $(5 \mathrm{~cm}$ in diameter and $10 \mathrm{~cm}$ length), which serves as hiding places for the animals. Crayfish $(20-25 \mathrm{~g})$ were fed twice a day $(09.00,17.00)$ by $2 \%$ of their biomass with artificial pelleted feed containing $35 \%$ protein. Water temperature was regularly checked twice a day with a thermometer. The food remainder, feces and moults were extracted daily from the reservoirs by siphoning. The oxygen content and $\mathrm{pH}$ of rearing tank was measured by an oxygen meter (OxiGuard $\AA$, Birkerød, Denmark) and a WTW pH-meter (Germany). Each temperature group was then divided into two groups to determine the CTMin and CTMax in separate trials. CTMin and CTMax trials were conducted in rectangular plastic containers $(0.8$ $\mathrm{m} \times 0.35 \mathrm{~m} \times 0.5 \mathrm{~m})$ containing thermostatically controlled water baths. Three containers were allocated for each acclimation group and 5 crayfish were randomly allocated to each container $(n=15)$. During the experiment, the crayfish were not fed. Continuous aeration was provided for all containers to maintain dissolved oxygen above $5 \mathrm{ppm}$ using an air blower. The photoperiod was maintained in $12 \mathrm{~h}$ light/12 $\mathrm{h}$ dark. The trials were separately conducted at cooling or heating rates of $0.3{ }^{\circ} \mathrm{C} \mathrm{min}{ }^{-1}$. CTMin or CTMax was determined as the sub lethal thermal point at which locomotory movements became disorganized and crayfish lost the ability to escape from conditions, which ultimately lead to death. The CTMin and CTMax values were calculated as the arithmetic mean of the collective endpoint of individuals of a random sample of crayfish. The $A R R$ was calculated by dividing the tolerance change by the total change in acclimation temperature according to Claussen (1977).

\section{Statistical Analysis}

Following determination of the normality and homoscedasticity of the data, a one-way ANOVA was used to compare CTM tolerance of the species (SPSS 20.1). Duncan's multiple range test (DMRT) was carried out for post hoc mean comparisons. Regression analysis was also carried out to evaluate the relationship between acclimation temperature and CTMin and CTMax $(\mathrm{p} \leq 0.05)$.

\section{Results}

Water quality parameters in the rearing tanks at three acclimation temperatures were maintained at 
levels appropriate for the species (Table 1). Thermal tolerance tests showed that acclimation temperatures $\left(15,20\right.$ and $\left.25^{\circ} \mathrm{C}\right)$ had significant effects on CTMin values of $A$. leptodactylus $(\mathrm{P} \leq 0.05)$. At the heating/cooling rate of $0.3^{\circ} \mathrm{C} \mathrm{min}{ }^{-1}$ the CTMin values ranged between 1.1 and $2.0^{\circ} \mathrm{C}$, while CTMax values ranged between 37.4 and $38.7^{\circ} \mathrm{C}$ (Table 2). During the CTMin trials, the crayfish, regardless of the acclimation temperatures, started to lose their balance and laid down laterally at temperatures of $3.0-5.0^{\circ} \mathrm{C}$, and all the crayfish crumpled at $0.5^{\circ} \mathrm{C}$. In the CTMax trials, the crayfish started to show overall spasms at $32.0-33.0^{\circ} \mathrm{C}$ secreting mucus like fluids at between 33.0 and $37.0^{\circ} \mathrm{C}$. The thermal tolerance polygon area was calculated as $364^{\circ} \mathrm{C}^{2}$ between 15 and $25^{\circ} \mathrm{C}$ acclimation temperatures used in the experiments (Figure 1). The overall ARR values were calculated as 0.07 for CTMin and 0.13 for CTMax values between 15 and $25{ }^{\circ} \mathrm{C}$ acclimation temperatures (Table 3).

Table 1. Water quality parameters in the rearing tanks.

\begin{tabular}{cccc}
\hline Water temperature $\left({ }^{\circ} \mathrm{C}\right)$ & Dissolved oxygen $(\mathrm{ppm})$ & $\mathrm{pH}$ & $\mathrm{NH}_{3}(\mathrm{mg} / \mathrm{L})$ \\
\hline $15.0 \pm 1.0$ & & & 0.0 \\
$20.0 \pm 1.0$ & $5.0-6.0$ & $6.60-7.40$ & \\
$24.9 \pm 1.0$ & & & \\
\hline
\end{tabular}

Table 2. CTMin and CTMax values of Astacus leptodactylus acclimated to 15,20 and $25^{\circ} \mathrm{C}$. Each value is a mean \pm standart deviation $(\mathrm{n}=15)$.

\begin{tabular}{lccc}
\hline & \multicolumn{3}{c}{ Acclimation Temperature } \\
\cline { 2 - 4 } & $15^{\circ} \mathrm{C}$ & $20^{\circ} \mathrm{C}$ & $25^{\circ} \mathrm{C}$ \\
\hline CTMin & $1.3 \pm 0.8^{\mathrm{ab}}$ & $1.1 \pm 0.7^{\mathrm{b}}$ & $2.0 \pm 0.8^{\mathrm{a}}$ \\
CTMax & $37.4 \pm 1.4^{\mathrm{a}}$ & $37.5 \pm 0.9^{\mathrm{a}}$ & $38.7 \pm 1.6^{\mathrm{a}}$ \\
\hline
\end{tabular}

Table 3. The calculated acclimation response ratios (ARR) for Astacus leptodactylus acclimated to 15,20 and $25^{\circ} \mathrm{C}$.

\begin{tabular}{lcccc}
\hline & & \multicolumn{3}{c}{ Acclimation Temperature } \\
\cline { 2 - 5 } & & $15-20^{\circ} \mathrm{C}$ & $20-25^{\circ} \mathrm{C}$ & $15-25^{\circ} \mathrm{C}$ \\
\hline$\Delta \mathrm{C}$ Tmin & -0.2 & 0.9 & 0.7 \\
$\Delta \mathrm{T}$ & 5 & 5 & 0.18 & 0.07 \\
$\mathrm{ARR}$ & $\sum_{\Delta \mathrm{CTmax}}^{夭}$ & -0.04 & 1.2 & 1.3 \\
$\Delta \mathrm{T}$ & 0.1 & 5 & 10 \\
$\mathrm{ARR}$ & $\sum^{\varpi}$ & 5 & 0.24 & 0.13 \\
\hline
\end{tabular}

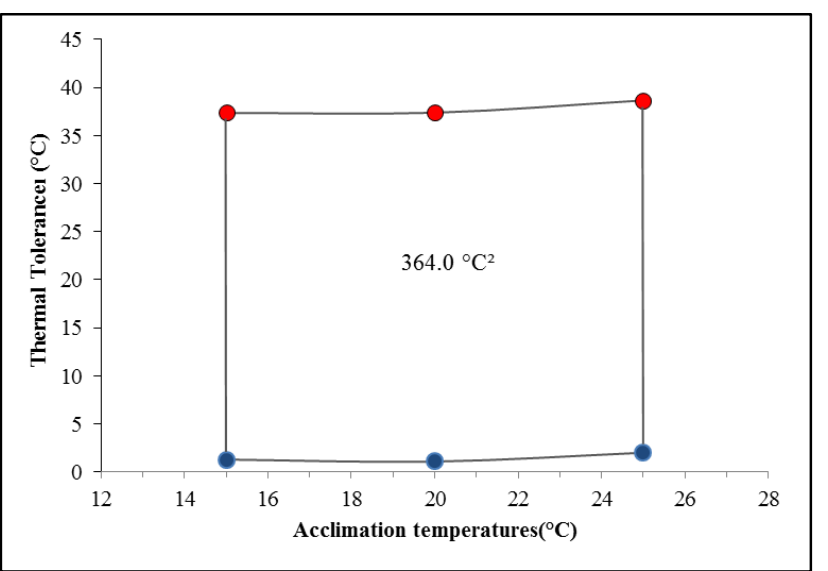

Figure 1. Thermal tolerance polygon of freshwater crayfish A. leptodacylus over three acclimation temperatures $\left(15,20\right.$ and $\left.25^{\circ} \mathrm{C}\right)$ using $C T M$ values.

\section{Discussion}

The importance of acclimation temperature on CTMin and CTMax values has been well documented for various freshwater crustacean species (Layne et al. 1987; Espina et al. 1993; Firkins 1993; Díaz et al.
2004; Manush et al. 2004). Similar to the above studies, acclimation temperature was also found to significantly influence the CTMin values of $A$. leptodactylus in the present study.

At $0.3^{\circ} \mathrm{C} \mathrm{min}^{-1}$ cooling/heating rate, the CTMin ranged from 1.1 to $2.0^{\circ} \mathrm{C}$, and the CTMax ranged from 37.4 to $38.7{ }^{\circ} \mathrm{C}$ for crayfish reared in three acclimation temperatures from 15 to $30^{\circ} \mathrm{C}$. The CTMax values obtained for A. leptodactylus were similar to those (ranged from 34.2 to $39.8{ }^{\circ} \mathrm{C}$ ) reported by Díaz et al. (2002) for Macrobrachium acanthurus.

A species living in the heterothermic environment must be tolerant to physiological temperature changes. The CTMax values in A. leptodactylus corresponded to total disorientation response and hampered locomotive activity resulting finally in death. Similar results were also reported by Hernández-Rodriguez et al. (1996) for Macrobrachium tenellum, Kumlu et al. (2010a) and Kumlu et al. (2010b) for Litopenaeus vannamei. During the CTMin trials, the crayfish, regardless of 
the acclimation temperatures, started to lose their balance and laid down laterally at temperatures of 5.0-3.0 ${ }^{\circ} \mathrm{C}$. After the CTMin tests, almost $100 \%$ of the animals recovered when transferred to pre-trial temperatures (Beitinger et al. 2000; Manush et al. 2004). However, at CTMax tests, the crayfish started to secrete mucus like fluids from their body at temperatures of $33.0-37.0^{\circ} \mathrm{C}$.

Thermal tolerance values varied within species with multiple estimates (Westhoff and Rosenberger 2016). For example, the thermal tolerance range for A. leptodactylus which was reported at $4-32{ }^{\circ} \mathrm{C}$ by Köksal (1998) and from 9 to $36^{\circ} \mathrm{C}$ by Firkins and Holdich (1993). Moreover, it is known that thermal tolerance zone is dependent on acclimation temperature, strain or population differences as well as the size of the animals used. In the current study, thermal tolerance polygon for A. leptodactylus at three acclimation temperatures $\left(15,20\right.$ and $\left.25^{\circ} \mathrm{C}\right)$ was calculated as $364^{\circ} \mathrm{C}^{2}$ (Figure. 1), but Firkins (1993) found the thermal tolerance area for $A$. leptodactylus originating from England at four acclimation temperatures $\left(5,10,20\right.$ and $\left.25^{\circ} \mathrm{C}\right)$ as $927^{\circ} \mathrm{C}^{2}$. Thermal tolerance traits could be attributed to geographic and climatic differences among ancestral source populations in this species. On the other hand, Manush et al. (2004) calculated thermal tolerance polygon for Macrobrachium rosenbergii at three acclimation temperatures $(25,30$ and $35^{\circ} \mathrm{C}$ ), and found a value of $255^{\circ} \mathrm{C}^{2}$, much lower than that of Herrera et al. (1998), who calculated this value as $>800{ }^{\circ} \mathrm{C}^{2}$ for the same species. Díaz et al. (2002) reported the polygon area of $644^{\circ} \mathrm{C}^{2}$ for $M$. acanthurus at wider acclimation temperatures (20, 23, 26, 29 and $32^{\circ} \mathrm{C}$ ).

Depending on the acclimation temperatures, the ARR values ranged from -0.04 to 0.24 for Turkish crayfish at the heating or cooling rate of $0.3^{\circ} \mathrm{C} \mathrm{min}^{-1}$. The overall ARR values were calculated as $0.13-0.24$, which are similar to those reported for some other crayfish species i.e. Astacus pallipes (0.12-0.18) by Spoor (1955) and Bowler (1963), Orconectes rusticus (0.23-0.25) by Claussen (1980) and Layne et al. (1987), O. virilis (0.15) by Claussen (1980). For a tropical crustacean, the giant freshwater prawn (M. rosenbergii), Herrera et al. (1998) reported the $A R R$ values as 0.44-0.58, while for a subtropical crayfish, the red claw (Cherax quadricarinatus), Díaz et al. (2004) reported the ARR as $0.33-0.66$. Hence, when we compare our results with those of the above, it is clear that A. leptodactylus is more resistant to low temperatures rather than the upper range and is a cold-temperature species. Culturing of A. leptodactylus in the southeastern region of the Mediterranean may be practiced in geographic zones where the environmental temperatures are near the final preferendum and do not exceed CTMax.

\section{Acknowledgements}

This study was financed by the Research Fund of the University of Çukurova (Adana, Turkey) by Project code number SUF2010D8 and was presented in International Symposium on Fisheries and Aquatic Science 2016, Antalya, Turkey, 3-5 November 2016.

\section{References}

Beitinger T, Bennett W, McCauley R. 2000. Temperature tolerances of North American freshwater fishes exposed to dynamic changes in temperature. Env Biol of Fish. 58:237-275.

doi: 10.1023/A:1007676325825

Bennett WA, Beitinger TL. 1997. Temperature Tolerance of the Sheepshead Minnow, Cyprinodon variegatus. Copeia 1997:77-87. doi: $10.2307 / 1447842$

Bowler K. 1963. A study of the factors involved in acclimatization to temperature and death at high temperatures in Astacus pallipes. I. Experiments on intact animals. J Cell Comp Physio. 62:119-132. doi: 10.1002/jcp.1030620203

Claussen DL. 1977. Thermal acclimation in ambystomatid salamanders. Comp Biochem Physio Part A: Physio. 58(4):333-340. doi: 10.1016/0300-9629(77)90150-5

Claussen DL. 1980. Thermal acclimation in the crayfish, Orconectes rusticus and O. virilis. Comp Biochem Physio Part A: Physio. 66(3):377-384. doi: 10.1016/0300-9629(80)90183-8

Cowles RB, Bogert CM. 1944. A preliminary study of the thermal requirements of desert reptiles. Bulle Ame Mus Nat His. 83:261-296.

doi: $10.1086 / 394795$

Díaz F, Sierra E, Denisse Re A, Rodríguez L. 2002. Behavioural thermoregulation and critical thermal limits of Macrobrachium acanthurus (Wiegman). J Therm Bio. 27(5):423-428. doi: 10.1016/S0306-4565(02)00011-6

Díaz F, Re AD, Sierra E, Amador G. 2004. Behavioral thermoregulation and critical limits applied to culture of red claw crayfish Cherax quadricarinatus (Von Martens). Fresh Cray. 14:90-98.

Diaz F, Salas A, Denisse Re A, Gonzalez M, Reyes I. 2011. Thermal preference and tolerance of Megastrea (Lithopoma) undosa (Wood, 1828; Gastropoda: Turbinidae). J Therm Bio. 36:34-37. doi: 10.1016/j.jtherbio.2010.10.004

Eme J, Bennett WA. 2009. Critical thermal tolerance polygons of tropical marine fishes from Sulawesi, Indonesia. J Therm Bio. 34:220-225.

doi: 10.1016/j.jtherbio.2009.02.005

Espina S, Diaz Herrera F., Bückle RLF. 1993. Preferred and avoided temperatures in the crawfish Procambarus clarkii (Decapoda, Cambaridae). J Therm Bio. 18:3539. 
doi: 10.1016/0306-4565(93)90039-V

Firkins I. 1993. Environmental tolerances of three species of freshwater crayfish. [PhD Thesis]. Nottingham University. 288 p.

Firkins I, Holdich DM. 1993. Thermal studies with three species of freshwater crayfish. Freshwater Crayfish. 9(1):241-248.

González RA, Díaz F, Licea A, Denisse Re A, Noemí Sánchez L, García-Esquivel Z. 2010. Thermal preference, tolerance and oxygen consumption of adult white shrimp Litopenaeus vannamei (Boone) exposed to different acclimation temperatures. $\mathrm{J}$ Therm Bio. 35(5):218-224.

doi: 10.1016/j.jtherbio.2010.05.004

Harlioğlu MM. 2004. The present situation of freshwater crayfish, Astacus leptodactylus (Eschscholtz, 1823) in Turkey. J Aquac. 230:181-187. doi: 10.1016/S0044-8486(03)00429-0

Hernández-Rodriguez M, Bückle-Ramirez F, DíazHerrera F. 1996. Critical thermal of Macrobrachium tenellum. J Therm Bio. 21:139-143. doi: 10.1016/0306-4565(95)00039-9

Herrera FD, Uribe ES, Ramirez LFB, Mora AG. 1998. Critical thermal maxima and minima of Macrobrachium rosenbergii (Decapoda: Palaemonidae). J Therm Bio. 23:381-385. doi: 10.1016/S0306-4565(98)00029-1

Holdich DM. 1993. A review of astaciculture: freshwater crayfish farming. Aq Liv Resour. 6:307-317. doi: 10.1051/alr:1993032

Huey RB, Stevenson RD. 1979. Integrating Thermal Physiology and Ecology of Ectothenns: A Discussion of Approaches Department. Am Zoo. 19:57-366.

Köksal G. 1988. Astacus leptodactylus in Europe. In: Holdich DM, Lowery RS (eds) Freshwater crayfish: biology, management and exploitation. Croom Helm, London: Timber Press. p. 365-400.

Kumlu M, Kumlu M, Turkmen S. 2010a. Combined effects of temperature and salinity on critical thermal minima of pacific white shrimp Litopenaeus vannamei (Crustacea: Penaeidae). J Therm Bio. 35:302-304. doi: 10.1016/j.jtherbio.2010.06.008

Kumlu M, Türkmen S, Kumlu M. 2010b. Thermal tolerance of Litopenaeus vannamei (Crustacea: Penaeidae) acclimated to four temperatures. $\mathrm{J}$ Therm Bio. 35:305-308. doi: $10.1016 /$ j.jtherbio.2010.06.009

Layne JR, Claussen DL, Manis ML. 1987. Effects of acclimation temperature, season, and time of day on the critical thermal maxima and minima of the crayfish Orconectes rusticus. J Therm Bio. 12:183-187. doi: 10.1016/0306-4565(87)90001-5

Manush SM, Pal AK, Chatterjee N, Das T, Mukherjee SC. 2004. Thermal tolerance and oxygen consumption of Macrobrachium rosenbergii acclimated to three temperatures. J Therm Bio. 29:15-19.

doi: 10.1016/j.jtherbio.2003.11.005

Paladino FV, Spotila JR, Schubauer JP, Kowalski KT. 1980. The critical thermal maximum- a technique used to elucidate physiologial stress and adaptation in fishes. Rev Can Bio. 39:115-122.

Pérez E, Díaz F, Espina S. 2003. Thermoregulatory behavior and critical thermal limits of the angelfish Pterophyllum scalare (Lichtenstein) (Pisces: Cichlidae). J Therm Bio. 28:531-537. doi: 10.1016/S0306-4565(03)00055-X

Re AD, Diaz F, Sierra E, Rodríguez J, Perez E. 2005. Effect of salinity and temperature on thermal tolerance of brown shrimp Farfantepenaeus aztecus (Ives) (Crustacea, Penaeidae). J Therm Bio. 30:618-622. doi: 10.1016/j.jtherbio.2005.09.004

Salas A, Díaz F, Re AD, Galindo-Sanchez CE, SanchezCastrejon E, González M, Licea A, Sanchez-Zamora A, Rosas C. 2014. Preferred Temperature, Thermal Tolerance, and Metabolic Response of Tegula regina (Stearns, 1892). J Shell Res. 33:239-246. doi: 10.2983/035.033.0123

Simčič T, Pajk F, Jaklič M, Brancelj A, Vrezec A. 2014. The thermal tolerance of crayfish could be estimated from respiratory electron transport system activity. J Therm Bio. 41:21-30. doi: $10.1016 /$ j.jtherbio.2013.06.003

Spoor WA. 1955. Loss and gain of heat-tolerance by the crayfish. T Bio Bull. 108:77-87. doi: $10.2307 / 1538399$

Tepler S, Mach K, Denny M. 2011. Preference versus performance: Body temperature of the intertidal snail Chlorostoma funebralis. Bio Bull. 220:107-117.

Westhoff JT, Rosenberger AE. 2016. A global review of freshwater crayfish temperature tolerance, preference, and optimal growth. Rev Fish Biol Fisheries 26:329349. doi: 10.1007/s11160-016-9430-5

Wickins JF, O'C Lee D. 2003. Crustacean Farming, Ranching and Culture, 2nd edition. Aqua Res. 34:269270.

doi: 10.1046/j.1365-2109.2003.00813.x 